Бояринова К.О.

канд. економ. наук, доцент

Михайленко А.А.

Національний технічний університет Украӥні «КПI»

\title{
ТЕХНОЛОГІЧНА КОНКУРЕНТОСПРОМОЖНІСТЬ ЯК ФАКТОР ІННОВАЦІЙНОГО РОЗВИТКУ ВИРОБНИЦТВА
}

\author{
ТЕХНОЛОГИЧЕСКАЯ КОНКУРЕНТОСПОСОБНОСТЬ КАК ФАКТОР \\ ИННОВАЦИОННОГО РАЗВИТИЯ ПРОИЗВОДСТВА
}

\section{TECHNOLOGICAL COMPETITIVENESS AS A FACTOR OF INNOVATIVE DEVELOPMENT OF PRODUCTION}

\begin{abstract}
Статтю присвячено розгляду та обтрунтуванню змісту поняття «технологічна конкурентоспроможність», висвітлено необхідність підвищення технологічної конкурентоспроможності виробничого підприємства як ключового фактору його розвитку. Визначено особливості управління підвищенням технологічної конкурентоспроможності. Запропоновано процедуру оцінювання технологічної конкурентоспроможності для прийняття рішень впровадження організаційноекономічних заходів, щзо складається $з$ таких етапів: оцінювання технологічної конкурентоспроможності; виявлення базового рівня стану основних засобів для визначення необхідності технологічних перетворень; оцінювання перспективних показників підвищення технологічної конкурентоспроможності; встановлення зміни технологічної конкурентоспроможності продукту; збалансування отриманих результатів для прийняття рішень щзодо впровадження технології. Розглянуто впровадження технологічної інновачї за використання бізнес-моделі. Сформульовано рекомендації щцодо підвищення технологічної конкурентоспроможності та удосконалення виробництва на інновачійній основі.
\end{abstract}

Ключовы слова: виробничо-економічна система, технологічна конкурентоспроможність, інноваційний розвиток

Статью посвящено рассмотрению и обоснованию содержания понятия «технологическая конкурентоспособность», освещено необходимость повышения технологической конкурентоспособности производственного предприятия как ключевого фактора его развития. Определены особенности управления повышением технологической конкурентоспособности. Предложена прочедура оценки технологической конкурентоспособности для принятия решений внедрения организационно-экономических мероприятий, состоящий из следующих этапов: оиенка технологической конкурентоспособности; выявления базового уровня состояния основных средств для определения необходимости технологических преобразований; оченивания перспективных показателей повышения технологической конкурентоспособности; установление изменения технологической конкурентоспособности продукта; сбалансирования полученных результатов для принятия решений по внедрению технологии. Рассмотрень внедрения технологической инновации при использовании бизнес-модели. Сформулировань 
рекомендации по повышению технологической конкурентоспособности $и$ совершенствования производства на инновационной основе.

Ключовы слова: производственно-экономическая система, технологическая конкурентоспособность, инновационное развитие.

The article deals with the essence and substantiation of the concept of "technological competitiveness," the need to improve the technological competitiveness of industrial enterprises as a key factor in its development is highlighted. The features management increased technological competitiveness are established. The procedure to assess technological competitiveness for decisions implementing organizational and economic measures is proposed. The procedure consists of the following stages: assessment of technological competitiveness; identify baseline condition of fixed assets to determine whether technological change; evaluation of promising indicators of increasing technological competitiveness; installation of technological change competitiveness of the product; balance of the results to make decisions on the implementation of the technology. The introducing technological innovations for the use of business models is considered. The study formulates recommendations to improve technological competitiveness and improving production on innovative basis.

Kyewords: industrial and economic system, technological competitiveness, innovation development

Вступ. Вітчизняні підприємства, маючи значні виробничі потужності, втрачають конкурентоспроможність, оскільки виробляють енергоємну продукцію та використовують застарілі технології, i, як наслідок, продукція $є$ високовартісною. Одним з основних аспектів розвитку сучасної економіки України $є$ технологічна модернізація. При цьому головним фактором технологічного оновлення підприємств $\epsilon$ інноваційний технологічний розвиток виробничої системи. Присутність однотипних виробництв на підприємствах, високий рівень витрат на розробку та освоєння нових продуктів, породжують необхідність пошуку адекватних варіантів забезпечення конкурентних переваг, що зорієнтовані на витратну частину зайняття конкурентних позицій.

Серед таких можливостей, особливе місце посідає підвищення технологічної конкурентоспроможності підприємства. Дослідженню, зазначеного напряму присвятили свої праці вчені та економісти, зокрема Близнюк С.В. [5], Піддубна Л.І. [10], Дорожкіна, О.К. [2], Коршунова Е.Д. [11], Оберемчук В.Ф. [6] та ін.

Постановка завдання. Метою дослідження $\epsilon$ розгляд теоретичних положень, обгрунтування науково-методичних аспектів щодо підвищення технологічної конкурентоспроможності виробничо-економічної системи підприємства для забезпечення інноваційного розвитку. Визначення технологічної конкурентоспроможності фактором інноваційного розвитку обумовлено такими завданнями як: встановлення місця технологічної переваги, в забезпеченні конкурентоспроможності ролі в інноваційному розвитку виробництва, визначення процедури оцінювання технологічної 
конкурентоспроможності, застосування інновацій як інструменту управління підвищенням технологічної конкурентоспроможності.

Методологія. Під час дослідження застосовувалася сукупність загальних та специфічних наукових методів, а саме: системний підхід для розроблення процедури оцінювання технологічної конкурентоспроможності підприємства, порівняльній аналіз.

Результати дослідження. Стан вітчизняної економіки потребує використання фінансових, інвестиційних, управлінських підходів щодо технологічного основлення промислових підприємств для створення базису інноваційного розвитку.

Інноваційний розвиток - це шлях, який базується на поглибленні поєднання цілей підприємства, його підсистем, цілей кожної особистості, яка прцює в колективі, вдосконаленні ії діяльності, вдосконаленні бізнес-процесів для досягнення загальних стратегічних цілей; тому його система управління повинна передбачати інтеграцію цілей, ресурсів, персоналу та його знань і мотивованості, дій (процесів та процедур менеджменту), безперервний розвиток творчого потенціалу працівників, колективну співпрацю, тощо [1]. Іноваційний розвиток підприємства - це процес господарювання, що спирається на безупинному пошуку і використанні нових способів і сфер реалізації потенціалу підприємств у мінливих умовах зовнішнього середовища у межах обраної місії та прийнятої мотивації діяльності й пов'язаний 3 модифікацією існуючих і формуванням нових ринків збуту [3, с.263].

Конкурентоспроможність підприємства - це здатність підприємства створювати, виробляти та продавати товари й послуги, цінові й нецінові якості яких привабливіші, ніж в аналогічної продукції [6, с.19].

Технологічна конкурентоспроможність - це спроможність підприємства конкурувати на ринку завдяки впровадженню інновацій, наукових розробок, винаходів, ноу-хау, нових способів чи методів виробництва та управління, що забезпечують створення на підприємстві унікального високотехнологічного продукту чи послуги, яка в результаті стає тією конкурентною перевагою, що максимізує прибуток компанії та сприяє підвищенню рентабельності та ефективності ії діяльності [11, с.84].

Тобто технологічна конкурентоспроможність виробництва - це здатність підприємства здійснювати постійне підвищення якості та ефективності виробничих процесів, а також впроваджувати нові технології, що розширюють сферу діяльності підприємства або підвищують іiі ефективність.

Управління забезпеченням технологічної конкурентоспроможності виробництва слід починатися з їі оцінювання, результати якого дозволять прийняти комплекс рішень відповідних стану виробничо-технічнлогічної 
системи. Процедуру оцінювання технологічної конкурентоспроможності наведено на рис. 1.

На першому етапі визначаються базові показники стану основних засобів та порівнюються з рентабельністю основних засобів. Далі відбувається виявлення базорого рівня основних засобів для визначення необхідності технологічних перетворень та приймається рішення щодо впровадження технологій. На третьому етапі оцінюються показники підвищення технологічної конкурентоспроможності, а саме показники потенціалу підвищення конкурентоспроможності та показники технологічної конкурентоспроможності впроваджуваного продукту. Наступним етапом $\epsilon$ виявлення потенційної спроможності до технологічних змін, що визначає рішення: використання наявних та створення необхідних здатностей технологічної конкурентоспроможності. На наступному етапі встановлюються зміни технологічної конкурентоспроможності продукту. Завершує процедуру збалансування отриманих результатів.

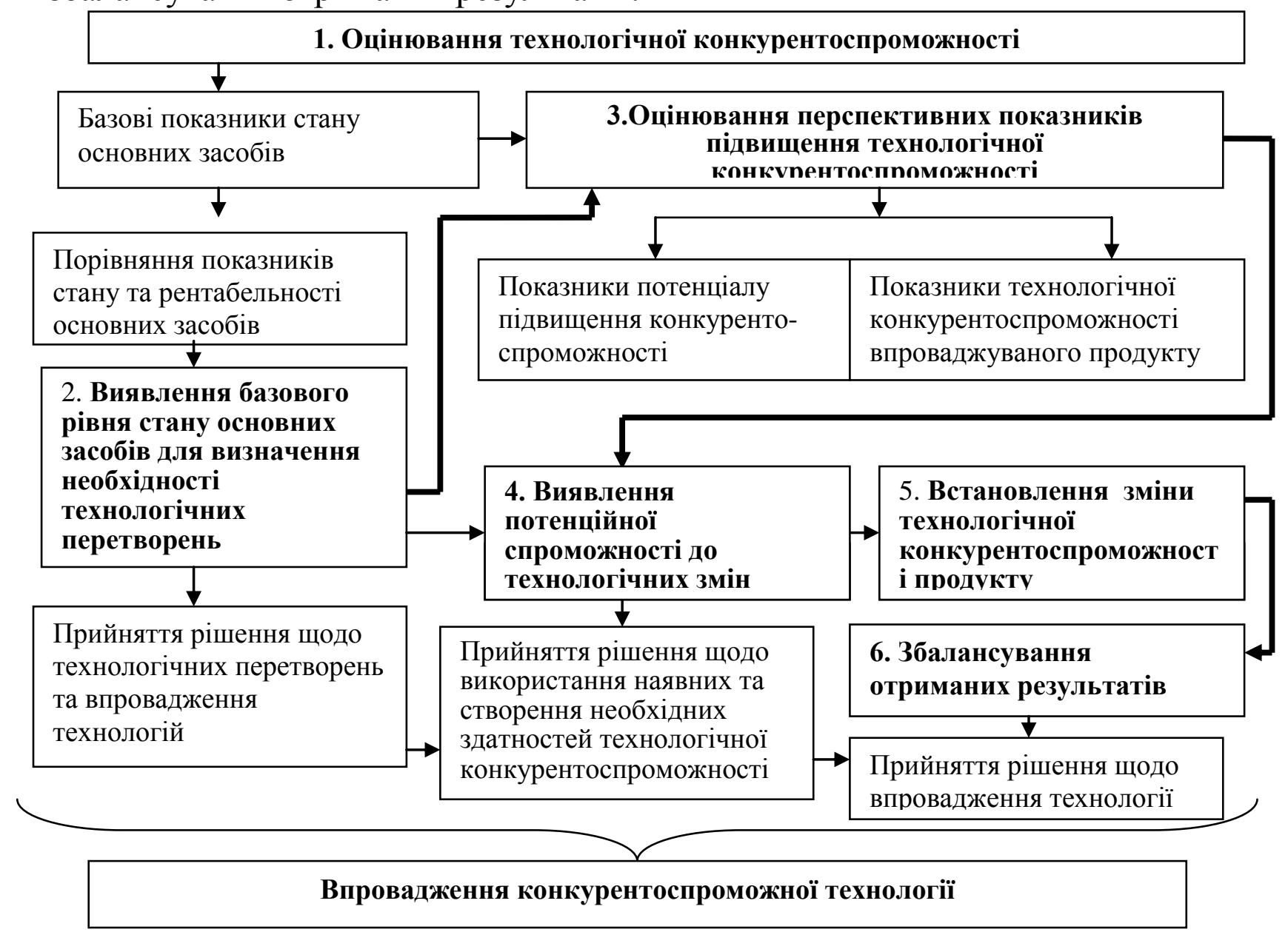

Рис. 1. Процедура оцінювання технологічної конкурентоспроможності виробництва для прийняття рішень впровадження організаційно-економічних заходів

Джерело: складено авторами 
Система базових показників стану основних засобів оцінювання технологічної конкурентоспроможності виробничо-економічної системи підприємства наведено в табл. 1.

Таблиця 1

Система базових показників стану основних засобів оцінювання технологічної конкурентоспроможності виробничо-економічної системи підприсмства

\begin{tabular}{|c|c|c|}
\hline $\begin{array}{c}\text { Напрям } \\
\text { оцінювання }\end{array}$ & Показник & Формула для розрахунку \\
\hline \multirow{4}{*}{$\begin{array}{c}\text { Стан основних } \\
\text { засобів }\end{array}$} & $\begin{array}{c}\text { Коефіцієнт зносу основних } \\
\text { виробничих засобів }\end{array}$ & $\begin{array}{l}\qquad K_{3}=\frac{\text { Сума зносу }}{B O \Phi 3_{\text {nервіс. }}} \cdot 100 \% \\
\text { де ВОФЗ - балансова вартість основних } \\
\text { засобів. }\end{array}$ \\
\hline & $\begin{array}{c}\text { Коефіцієнт придатності } \\
\text { основних виробничих } \\
\text { засобів } \\
\end{array}$ & \begin{tabular}{l}
\multicolumn{4}{c}{$K_{n p}=1-K_{3}$} \\
Де $K_{3}-$ коефіцієнт зносу основних \\
засобів.
\end{tabular} \\
\hline & $\begin{array}{l}\text { Коефіцієнт оновлення } \\
\text { основних засобів }\end{array}$ & $\begin{array}{l}K_{\text {он }}=\frac{B O 3_{n}}{B O 3_{\kappa .}} \cdot 100 \% \\
\text { де ВО3 }- \text { вартість введених та } \\
\text { оновлених основних засобів; } \\
\text { ВО3к - балансова вартість основних } \\
\text { засобів. }\end{array}$ \\
\hline & $\begin{array}{c}\text { Коефіцієнт вибуття основних } \\
\text { виробничих засобів }\end{array}$ & $\begin{array}{l}\qquad \text { Квиб. }=\frac{B O 3_{\text {виб }}}{B O 3_{n .}} \cdot 100 \% \\
\text { де ВОЗ - вартість виведених основних } \\
\text { засобів за звітний період. }\end{array}$ \\
\hline $\begin{array}{l}\text { Рентабельність } \\
\text { використання }\end{array}$ & $\begin{array}{c}\text { Рентабельність використання } \\
\text { основних засобів }\end{array}$ & $\begin{array}{l}R_{O B \Phi}=\frac{B П}{B O 3_{c p}} \cdot 100 \% \\
\text { де ВП - валовий прибуток від реалізації } \\
\text { (робіт, послуг); } \\
\text { ВОЗ }{ }_{\text {ср }}-\quad \text { середньорічна вартість } \\
\text { відповідно основних виробничих } \\
\text { фондів. }\end{array}$ \\
\hline
\end{tabular}

Джерело: складено за використання показників [12]

Для оцінювання рівня потенціалу підвищення технологічної конкурентоспроможності в інноваційному розвитку доцільно використовувати таку систему показників як наведено в табл. 2. 
Таблиця 2

\section{Система показників оцінювання потенціалу підвищення} технологічної конкурентоспроможності

\begin{tabular}{|c|c|c|c|}
\hline Група & Показники & $\begin{array}{c}\text { Умовне } \\
\text { познач } \\
\text { ення } \\
\end{array}$ & $\begin{array}{c}\text { Формула для } \\
\text { розрахунку }\end{array}$ \\
\hline \multirow{2}{*}{$\begin{array}{l}\text { 1. Показники } \\
\text { наукового } \\
\text { потенціалу } \\
\text { (НП) }\end{array}$} & $\begin{array}{c}\text { Частка чисельності персоналу, зайнятого } \\
\text { дослідженнями і розробками до чисельності } \\
\text { зайнятих на підприємстві }\end{array}$ & H1 & \multirow{2}{*}{$H \Pi=H 1+H 2$} \\
\hline & $\begin{array}{c}\text { Відношення чисельності докторів, } \\
\text { кандидатів, аспірантів до чисельності } \\
\text { зайнятих на підприємстві } \\
\end{array}$ & $\mathrm{H} 2$ & \\
\hline \multirow{2}{*}{$\begin{array}{l}\text { 2. Показники } \\
\text { кадрового } \\
\text { потенціалу } \\
\text { (КП) }\end{array}$} & $\begin{array}{l}\text { Частка працюючих з вищою освітою до } \\
\text { чисельності зайнятих на підприємстві }\end{array}$ & K1 & \multirow{2}{*}{$K \Pi=K 1+K 2$} \\
\hline & $\begin{array}{c}\text { Відношення на підприємстві учнів та тих, } \\
\text { що навчаються }\end{array}$ & К2 & \\
\hline \multirow{3}{*}{$\begin{array}{l}\text { 3. Показники } \\
\text { технічного } \\
\text { потенціалу } \\
\text { (ТП) }\end{array}$} & Коефіцієнт придатності основних засобів & $\mathrm{T} 1$ & \multirow{3}{*}{$T \Pi=T 1+T 2+T$} \\
\hline & Коефіцієнт оновлення основних засобів & $\mathrm{T} 2$ & \\
\hline & Фондоозброєність праці & $\mathrm{T} 3$ & \\
\hline \multirow{2}{*}{$\begin{array}{c}\text { 4. Показники } \\
\text { фінансово- } \\
\text { економічного } \\
\text { потенціалу } \\
\text { (ФЕП) }\end{array}$} & $\begin{array}{c}\text { Відношення обсягу інвестицій в основний } \\
\text { капітал до обсягу випускної продукції }\end{array}$ & E1 & \multirow{2}{*}{$\Phi E \Pi=€ 1+\epsilon 2$} \\
\hline & $\begin{array}{c}\text { Відношення внутрішніх витрат на } \\
\text { дослідження і розробки до обсягу продукції }\end{array}$ & $\epsilon 2$ & \\
\hline \multirow{3}{*}{$\begin{array}{l}\text { 5. Показники } \\
\text { інформаційно- } \\
\text { комунікаційної } \\
\text { складової (IКС) }\end{array}$} & Кількість ПК до кількості робітників & I1 & \multirow{3}{*}{$\begin{array}{l}I K C=I 1+I 2+I \\
(210)\end{array}$} \\
\hline & $\begin{array}{c}\text { Частка кількості абонентів мобільного } \\
\text { зв язку до чисельності працюючих }\end{array}$ & $\mathrm{I} 2$ & \\
\hline & Частка загальної кількості робочих місць & $\mathrm{I} 3$ & \\
\hline \multicolumn{2}{|c|}{$\begin{array}{c}\text { Показник рівня потенціалу підвищення технологічної } \\
\text { конкурентоспроможності в інноваційному розвитку }\end{array}$} & \multicolumn{2}{|c|}{$I \Pi=\sqrt[5]{H \Pi \times K \Pi \times T \Pi \times \Phi E \Pi}$} \\
\hline
\end{tabular}
Джерело: [14,15]

Доречно використати такі показники технологічної конкурентоспроможності продукту [15, с.38]:

- показник інтегрального технічного рівня:

$$
K_{n m}=x_{1} \frac{a_{1}}{a_{0}}+x_{2} \frac{b_{1}}{b_{0}}+x_{3} \frac{c_{1}}{c_{0}}+x_{4} \frac{d_{1}}{d_{0}},
$$

де $\mathrm{x}_{1} \ldots \mathrm{x}_{4}-$ коефіцієнти вагомості основних споживчих показників продукту, що характеризують його технічний рівень $\left(\mathrm{x}_{1}+\mathrm{x}_{2}+\mathrm{x}_{3}+\mathrm{x}_{4}=1\right)$;

$\mathrm{a}_{1} \ldots \mathrm{d}_{1}-$ значення основних споживчих показників продукту, що характеризують його технічний рівень після модернізації; 
$\mathrm{a}_{0} \ldots \mathrm{d}_{0}-$ значення основних споживчих показників продукту, що характеризують його технічний рівень до модернізації.

- рівень (індекс) ефективності (конкурентоспроможності) нового продукту відносно базового [15, с.40]:

$$
y=\frac{P \pi K}{\left(\frac{U_{m} Д_{m}}{K_{y . m .}}+\frac{U_{m} Д_{m}}{t}+U_{e} w Д_{e}\right)},
$$

де $\mathrm{P}$ - рівень випуску продукції;

$\pi$ - рівень надійності технології;

К - рівень якості продукту, виробленого за новою технологією;

$\mathrm{U}_{\mathrm{m}}, \mathrm{U}_{\mathrm{M}}, \mathrm{U}_{\mathrm{e}}$ - індекси цін обладнання, праці, енергії;

$\mathrm{K}_{\mathrm{y} \cdot \mathrm{m} \cdot}$ - індекс енергометричності;

$\mathrm{t}$ - рівень середнього терміну служби обладнання;

$Д_{\mathrm{m}}, Д_{\mathrm{m}}, Д_{\mathrm{e}}-$ частки грошових витрат в технологічній структурі виробництва (Д

Після прийняття рішень щодо технологічної модернізації є необхідним застосування методичного апарату для збалансування заходів його впровадження.

Впровадження організаційно-економічних заходів підвищення технологічної конкурентоспроможності виробництва має комплексно охоплювати виробничо-економічну систему підприємства та визначати процедури досягнення поставленої мети. Саме тому інструментом інноваційного розвитку підприємства на основі технологічної конкурентоспроможності обрано бізнес-модель.

Для підвищення технологічної конкурентоспроможності підприємств зі специфічним виробництвом пропонується вкористовувати інноваційну бізнесмодель на основі бізнес-моделі «Канвас» (Canvas Business Model), яка дозволяє здійснити детальний опис проекту. Як приклад практичного застосування пропонованих рекомендацій сформовано бізнес-модель (рис.2) для підприємства ТОВ «СІT», підвищення технологічної конкурентосмпроможності якого буде здійснюватися на основі комп'ютероного 3D проектування ювелірних виробів та оснастки.

Розглянемо докладніше змістовні блоки пропонованої бізнес-моделі відповідно методології [16]: ключові партнери, ключові види діяльності, ціннісна пропозиція, взаємовідносини з клієнтами, цільові сегменти, ключові ресурси, канали збуту, структура витрат, структура доходів [16].

Ключові партнери. До введення інновації ТОВ «СіТ» співпрацює із багатьма перевіреними роками постачальниками. Після проведення модернізації зміниться кількість та різновид постачальників, які співпрацюють з ТОВ «СіТ». 
3 переліку постачальників буде виключено постачальника витратних матеріалів.

Ключові види діяльності. Виробництво ювелірної продукціїі з золота, срібла та їх сплавів із використанням дорогоцінного каміння.

Для виготовлення продукції потрібні такі бізнес-процеси: навчання персоналу, маркетингові дослідження, робота із постачальниками, організація і контроль виготовлення продукції, транспортування (логістика).

Після проведення модернізації цей блок не зазнає значних змін, бо вони відбудуться лише під час організації та самого процесу виробництва продукції. Тобто в деякій міри зміниться тільки складова частина технології.

Ціннісна пропозиція. Після проведення модернізації відбудуться значні покращення в якості продукції завдяки вдосконаленню дизайну, оскільки використання 3D-принтеру надає змогу робити майже будь-який вигляд прикрас, які було неможливо виконати раніше, а тим паче за такий короткий термін.

Взаємовідносини з клієнтами. Після проведення модернізації особливий акцент буде зроблено на персональну підтримку та інтереси окремого споживача як індивідуальну особистість та представника певної групи (тобто, сегменту) з певними потребами та інтересами.

Цільові сегменти. Основними споживачами прикрас із золота, безумовно, $є$ жінки, але після проведення модернізації будуть також проведені зміни маркетингової політики та створено більш широкий асортимент унікальних прикрас для чоловіків. Тому, частка чоловіків буде збільшена до $30 \%$. Також варто звернути увагу на споживачів віком до 35 років, тобто молодь, яку цікавлять різноманітні цікаві прикраси. Їх частка має збільшитися до $40 \%$.

Ключові ресурси. Після проведення модернізації відбудяться зміни в виробничих ресурсах, оскільки з'явиться нове обладнення, що також відобразиться й на інших:

1) інтелектуальні ресурси. В дизайні прикрас та технології їх виготовлення. Тобто застосовуються такі напрями:

- майстер-моделі золотих i срібних прикрас, на основі яких створюватимуться пластмасові дублікати методом заливки в гумові або силіконові прес-форми;

- створення прикрас за індивідуальним дизайном (замовленням);

- серійне виробництво ювелірних виробів, біжутерії або сувенірів;

- створення виставкових зразків, призначених для демонстрації можливостей майбутньої серійної продукції;

- створення продукції гарячого або холодного формування ювелірних прикрас; 


\begin{tabular}{|c|c|c|c|c|c|}
\hline Ключові партнери & \multicolumn{2}{|c|}{ Ключові види діяльності } & $\begin{array}{c}\text { Ціннісна } \\
\text { пропозиція }\end{array}$ & $\begin{array}{c}\text { Взаємовідносини } 3 \\
\text { кліснтами }\end{array}$ & Цільові сегменти \\
\hline \multirow{3}{*}{$\begin{array}{c}\text { Постачальником } \\
\text { дорогоцінних } \\
\text { металів є ТОВ } \\
\text { «Київська русь». } \\
\text { Постачальником } \\
\text { полірувального } \\
\text { обладнання є ТОВ } \\
\text { «Авалон». } \\
\text { ЧП «Калібрі } \\
\text { джемс», «Renobe», } \\
\text { «Ритм-Rк», } \\
\text { «Трейд». } \\
\text { (Зменшення } \\
\text { кількості) }\end{array}$} & \multicolumn{2}{|c|}{$\begin{array}{c}\text { Виробництво ювелірної продукціїі з } \\
\text { золота, срібла та їх сплавів із } \\
\text { використанням дорогоцінного } \\
\text { каміння. } \\
\text { Для виготовлення продукиії потрібні } \\
\text { такі бізнес-процеси: } \\
\text { навчання персоналу } \\
\text { маркетингові дослідження } \\
\text { робота із постачальниками } \\
\text { організація і контроль виготовлення } \\
\underline{\text { продукиїі, логістика }} \\
\end{array}$} & \multirow{3}{*}{$\begin{array}{l}\text { Якісна продукція } \\
\text { Доступні иіни } \\
\frac{\text { Цікавий дизайн }}{\text { Широкий }} \\
\frac{\text { асортимент }}{\text { Сервіс }} \\
\frac{\text { Кастомізаиія }}{\underline{\text { Унікальна }}} \\
\underline{\text { продукиія }}\end{array}$} & $\begin{array}{c}\text { Персональна підтримка } \\
\text { Відповідальність перед } \\
\text { споживачами. } \\
\text { Інформаційна підтримка } \\
\text { та забезпечення } \\
\text { логістичних послуг. }\end{array}$ & \multirow{3}{*}{$\begin{array}{c}\text { Дохід: ринок споживачів } \\
\text { з середнім і високим } \\
\text { рівнем доходів. } \\
\text { Стать: жінки - 70\% } \\
\text { Чоловіки - 30\% } \\
\text { Вік: } 35-50 \text { років }-60 \% \\
\text { До } 35 \text { років }-40 \% \\
\end{array}$} \\
\hline & \multirow{2}{*}{\multicolumn{2}{|c|}{$\begin{array}{c}\text { Ключові ресурси } \\
\text { Матеріальні ресурси: Виробниче } \\
\text { приміщення з обладненням в м. Біла } \\
\text { Церква } \\
\text { Інтелектуальні ресурси: } \\
\text { Дизайн прикрас та технологія } \ddot{x} \\
\underline{\text { виготовлення }} \\
\text { Працівники: більше ніж } 60 \text { осіб (3 } \\
\text { вищою або середніьою- спеціальною } \\
\text { освітою) }\end{array}$}} & & Канали збуту & \\
\hline & & & & $\begin{array}{c}\text { Україна та країни СНД. } \\
\text { Прямі та непрямі канали } \\
\text { збуту: роздрібна та оптова } \\
\text { торгівля. } \\
\text { Iнтернет торгівля }\end{array}$ & \\
\hline \multicolumn{2}{|c|}{ Структура витрат } & \multirow{2}{*}{\multicolumn{2}{|c|}{$\begin{array}{c}\text { Структура доходів } \\
\text { Золоті вироби - } 25 \% \\
\text { Срібні вироби - 30\% } \\
\text { Вироби зі сплавів - } 45 \% \\
\text { (Тенденція до збільшення) } \\
\end{array}$}} & \multicolumn{2}{|c|}{ Фінансові потоки } \\
\hline \multicolumn{2}{|c|}{$\begin{array}{l}\text { Виробничі витрати -55\% } \\
\text { Адміністративні витрати - } 17 \% \\
\text { Логістичні витрати }-26 \% \\
\text { Фінансові витрати та інші - } 2 \% \\
\text { (Тенденція до зменшення) }\end{array}$} & & & \multicolumn{2}{|c|}{$\begin{array}{c}\text { Ефективне використання фінансових ресурсів } \\
\text { надає можливість підвищувати рентабельність, } \\
\text { раціонально використовувати ресурси та } \\
\text { впроваджувати інновації, здійснюючи } \\
\text { переобладнення } \\
\end{array}$} \\
\hline
\end{tabular}

Рис. 2. Інноваційна бізнес-модель ТОВ «СІТ»

Джерело: складено автором на основі методології [16] 
2) працівники. Більше ніж 60 осіб (з вищою або середніьою-спеціальною освітою) працюють на підприємстві, але замість восковиків необхідно найняти працівників, які мають навички роботи з CAD-програмами.

Канали збуту. Після проведення модернізації змін в каналах збуту цей інноваційний проект не передбачає, однак зміна дизайну та цін веде до розширення та часткової зміни цільових споживачів, а завдяки їх «омолодженню» збільшиться частка продажів через інтернет мережу.

Структура витрат. Після проведення модернізації як i раніше найбільша частина витрат буде нележати виробничим витратам (прямі матеріальні витрати, на оплату праці та загальновиробничі), які будуть складати більше ніж 55\%.

Структура доходів. Після проведення модернізації доходи мають збільшитися завдки зменшенню виробничих витрат, розширенню асортименту та покращення логістики в поєднанні 3 покращеною маркетинговою політикою. Також мають збільшитися продажі прикрас з сплавів та складати більше ніж 45\%. Завдяки використанню можливостей 3D-принтера та вдосконаленого дизайну, такі прикраси будуть мати більш конкурентоспроможний вигляд та привертати увагу нових споживачів.

Стратегія, яка розробляється для даного підприємства стосується підвищення конкурентоспроможності за рахунок розширення асортименту, тобто стратегія центрованої диверсифікації з урахуванням технологічного оновлення виробництва.

Висновки. Розгляд теоретичних та наукових надбань щодо технологічної конкурентоспрможності дозволив констатувати, що підприємство має забезпечувати технологічну та економічну ефективність, тобто вдало сполучати технічну та економічну складові для забезпечення конкурентних переваг. Як наукова новизна предоставленого дослідження полягає в набуті подальшого розвитку трактування технологічної конкурентоспроможності як здатності підприємства здійснювати постійне підвищення якості та ефективності виробничих процесів, а також впроваджувати нові технології, які розширюють сферу діяльності підприємства або підвищують їі ефективність.

На основі експлікації науково-методичних положень запропоновано процедуру оцінювання технологічної конкурентоспроможності для прийняття рішень впровадження організаційно-економічних заходів, що складається 3 таких етапів: оцінювання технологічної конкурентоспроможності; виявлення базового рівня стану основних засобів для визначення необхідності технологічних перетворень; оцінювання перспективних показників підвищення технологічної конкурентоспроможності; встановлення зміни технологічної конкурентоспроможності продукту; збалансування отриманих результатів для прийняття рішень щодо впровадження технології. 
Впровадження запропонованих заходів в комплексі надасть можливість підвищити технологічну конкурентоспроможність виробничого підприємства, що сприятиме інноваційному розвитку та зміцнть становище серед конкурентів на ринку.

Подільші дослідження будуть спрямовані на управлінські технології забезпечення технологічної конкурентоспроможності виробничо-економічної системи підприємства.

\section{Література:}

1. Підкамінний I.M. Системні фактори впливу на інноваційний розвиток / I.M. Підкамінний, В.С. Ціпуринда // Ефективна економіка - 2011. - №3 - Режим доступу: URL: http://www.economy.nayka.com.ua/?op=1\&z=480.

2. Портер М. Стратегія конкуренції / М. Портер, пер. з англ. - К.: Основи, 2008. - 390с.

3. І Ілляшенко С. М. Маркетинг. Менеджмент. Інновації: монографія / С. М. Ілляшенко. Суми: ТОВ «Друкарський дім «Папірус», 2010. - 623 с.

4. Азоев Г.Л. Конкурентні переваги фірми / Г.Л. Азоев, А.П. Челенков. - М.: Новини, 2000. $-256 \mathrm{c}$.

5. Близнюк С.В. Конкурентний потенціал підприємництва як категорія сучасних економічних досліджень / С.В Близнюк, А.В. Остапенко / Інвестиції: практика та досвід. - 2011. - №7. - с.41-42.

6. Оберемчук В.Ф. Забезпечення конкурентоспроможності підприємства: стратегічні аспекти: автореферат дис. на здобуття наук. ступеня д.е.н. Спец. 08.06.01 / В.Ф. Оберемчук. - К.: Київський нац. ек. ун-т, 2009. - 19с.

7. Комличенко Є.I. Конкурентоспроможність підприємства / Є.І. Комличенко (Антонюк) // Шляхи розвитку машинобудування : I Міжн. наук.-практ. конф., 16-18 травн. 2006 p.: зб. тез. доп. - Запоріжжя: ЗЦНТЕІ, 2006. - c.26-27.

8. Коломієць І.Ф. Підвищення рівня конкурентоспроможності підприємства в системі факторів інтернаціоналізації / І.Ф. Коломієць / Конкуренція. -2007. - № 3. - с.16-26.

9. Закон України «Про інноваційну діяльність» від 04 липня 2002 року, №40-IV // Відомості Верховної Ради України. - 2002.- №36. - С. 882-892.

10. Піддубна Л.І. Технологічна конкурентоспроможність підприємства і сучасні стратегії іï формування / Л.І. Піддубна // Вісник ХДЕУ. - 2001. - №4.(20) - с.95-99.

11. Коршунова Е.Д. Підвищення технологічної конкурентоспроможності промислового підприємства на основі використання технологій інвестування інноваційним обладнанням / Е.Д. Коршунова, П.В. Миколаїв // Вісник МГТУ «Станкін». - 2011. №3 (15) - c.178-181.

12. Юрчишена Л.В. Аналіз ефективності використання основних засобів / Л. В. Юрчишена, С. М. Волинець // Ефективна економіка - 2011. - №8 - Режим доступу: URL: http://www.economy.nayka.com.ua/?op=1\&z=668.

13. Офіційний сайт державної служби статистики України [Електронний ресурс]. Режим доступу: URL: http://www.ukrstat.gov.ua.

14. Янковський О.Г. Конкурентоспроможність підприємства: оцінка рівня та напрями підвищення: монографія / О.Г. Янковський. - Одеса: Атлант, 2013. -34-65 с.

15. Захаркін О.О. Оцінка інноваційного потенціалу підприємств у контексті інноваційного розвитку регіонів / О. О. Захаркін, М. О. Харченко, А. Л. Івахнова - // Механізм регулювання економіки - 2012. - №4 - c.216-221. 
16. Соолятте А. Ю. Бізнес-модель компанії: розробка та опис [Електронний ресурс] / А.Ю. Соолятте // ТОВ «Фінексперт-тренінг» - Режим доступу: www.finexpert.ru 